\title{
The First Record of Nesting of the Osprey on the High-voltage Power Pole in the Sayan Mountains, Russia
}

\section{ПЕРВЫЙ СЛУЧАЙ ГНЕЗДОВАНИЯ СКОПЫ НА ОПОРЕ ВЫСОКОВОЛЬТНОЙ ЛЭП В САЯНЕ, РОССИЯ}

\author{
Karyakin I.V. (Center of Field Studies, N. Novgorod, Russia), \\ Nikolenko E.G. (Sibecocenter LLC, Novosibirsk, Russia), \\ Prommer M. (Herman Ottó Institute, Budapest, Hungary), \\ Kazi R. (Danube-Ipoly National Park, Budapest, Hungary) \\ Карякин И.В. (Центр полевых исследований, Н.Новгород, Россия), \\ Николенко Э.Г. (ООО «Сибэкоцентр», Новосибирск, Россия), \\ Проммер М. (Институт Германа Отто, Будапешт, Венгрия), \\ Кази Р. (Дунай-Иполи национальный парк, Будапешт, Венгрия)
}

Контакт:

Игорь Карякин Центр полевых иссиедований 603109, Россия Нижний НовгороА ул. Нижегородская, 3-29 тел.: +78314333847 ikar_research@mail.ru

Эмьвира Николенко ООО "Сибэкоцентр" 630090 , Россия Новосибирск а/я 547

тел.: +79231501279 elvira_nikolenko@mail.ru

DOI: $10.19074 / 1814-8654-2017-34-100-104$

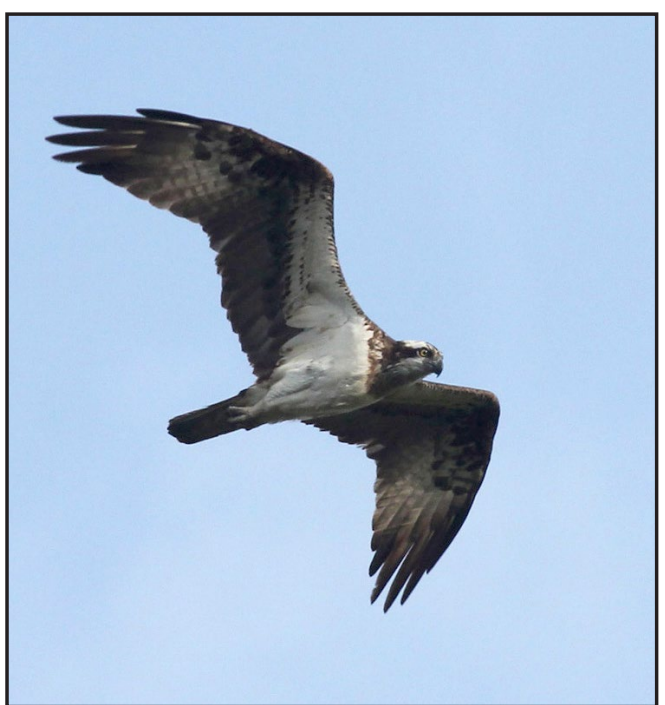

Согласно данным Красных книг Красноярского края и Республики Хакасия скопа (Pandion haliaetus) сохраняется сравнительно обычной на реках Саянской горной системы (Кустов, 1978; 1982; Стахеев, 1983, 1985; Кохановский, 1991; Валюх, 1991; 1996; Савченко и мр., 2011 ; Гаврилов, Баранов, 2014). Ешё в начале $\mathrm{XX}$ в. скопа гнездилась в тайге Саяна на Аостаточно больших высотах на Ойском озере и реках Буйбе и Куярте (Тугаринов, Бутурлин, 1911; Сушкин, 1914), откуда данные о гнездовании в последние Аесятилетия отсутствуют. Предполагается, что в горно-таёжной зоне северного Саяна гнездится не более 200 пар скоп: 120-150 пар в горно-таёжной зоне юга Красноярского края, преимушественно
Скопа (Pandion haliaetus). Фото А. Левашкина. Osprey (Pandion haliaetus). Photo by A. Levashkin.

The Osprey (Pandion haliaetus) stays relatively common on rivers of Sayan mountain system within the Republic of Khakassia and Krasnoyarsk Kray (Kustov, 1978; 1982; Staheev, 1983, 1985; Kohanovskiy, 1991; Valyukh, 1991; 1996; Savchenko et al., 2011; Gavrilov, Baranov, 2014). It's assumed that there are no more than 200 pairs of Ospreys nesting in mountain-taiga region of the northern Sayan (Savchenko et al., 2011; Gavrilov, Baranov, 2014), the number of which has been growing the recent years (unpublished data by authors; Kovyrtsev, 2012).

Currently, all discovered pairs of Ospreys nested on tops of trees, often withering or with withered top, growing on sides of river valleys or among meandering river courses in valleys, on altitudes less than $1000 \mathrm{~m}$ above the sea level. In Western Sayan in 1999-2015 the Osprey nested in altitude range from 503 to $913 \mathrm{~m}$ above the sea level (fig. 1-1). The only nesting point which was off those limits was found on lake Bedooyskoye in the upstream of the Bedooy river. Here the Ospreys made a nest on a withering tree growing $1440 \mathrm{~m}$ above sea level.

There was an inhabited Osprey nest found on $22^{\text {th }}$ of June, 2016 on the route along Bolshoy On river at $1321 \mathrm{~m}$ above 


\section{Contact:}

Igor Karyakin

Center of Field Studies

Nizhegorodskaya str.,

3-29

Nizhniy Novgorod

Russia, 603109

tel.: +78314333847

ikar_research@mail.ru

Elvira Nikolenko

Sibecocenter LLC

P.O. Box 547

Novosibirsk

Russia, 630090

tel.: +79231501279

elvira_nikolenko@mail.ru

Matyas Prommer

Herman Ottó Institute

Park u. 2., Budapest,

Hungary, 1223

prommer.matyas@

mme.hu

Robert Kazi

Danube-Ipoly National

Park Directorate

Kolto u. 21., Budapest,

Hungary, 1121

kazi.robert@dinpig.hu в Саянах (Савченко и Ар., 2011) и около 40-50 пар в Хакасии, из них на реках горно-таёжной части, преимушественно в Саянах, более 80 \% гнездяшихся пар (Гаврилов, Баранов, 2014). Вероятно, от этих оценок численности можно отталкиваться как от минимальных, потому что сп^ошных близких по времени учётов скопы на горно-таёжных реках Саяна $\Delta о$ сих пор не проводилось, мониторинг ведётся кишь на р. Бол. Абакан (Хакасия) и на Саяно-Шушенском водохранилише (Красноярский край), а численность скопы здесь определённо растёт, как минимум на территориях с ведушимся мониторингом в бассейне Абакана (наши данные) и в каньоне Енисея в Саяно-Шушенском заповеднике (Стахеев, 2003). На последней территории, согласно Аанным Аетописи природы 1980 года, было обнаружено 3 жилых гнезда скопы, а по итогам инвентаризации 2012 года их зарегистрировано 16, из которых 12 - жилые; с учётом слётков текушего года численность скопы в заповеднике "Саяно-Шушенский" в 2012 г. составила более 40 особей, что в четыре раза больше чем 30 лет назал (Стахеев, 1983; 1988; Ковырцев, 2012).

В современный период все выявленные пары скоп гнездились на вершинах деревьев, часто суховершинных или усыхаюших, растуших на скионах речных Аолин, либо среди меандрируюших русел рек в долинах, на высотах ниже 1000 м нал уровнем моря. В Западном Саяне, где исследования Центра полевых исследований и Российской сети изучения и охраны пернатых хишников в 1999-2015 гг. велись преимушественно на р. Бол. Абакан, скопа гнездилась в диапазоне высот от 503 до 913 м нац уровнем моря (рис. 1-1). Аишь

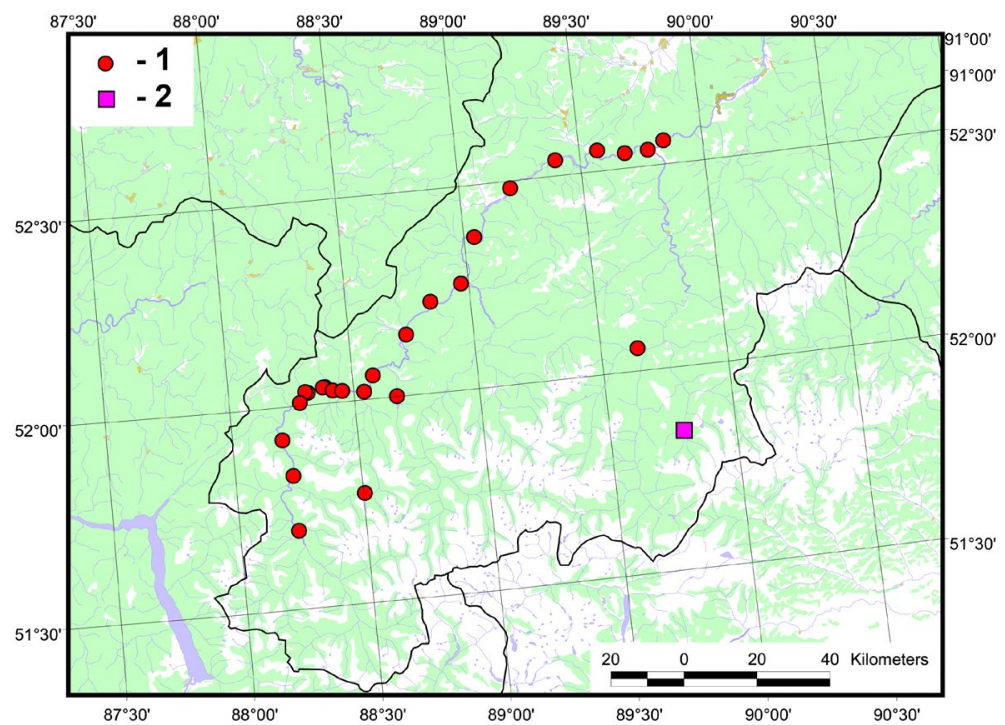

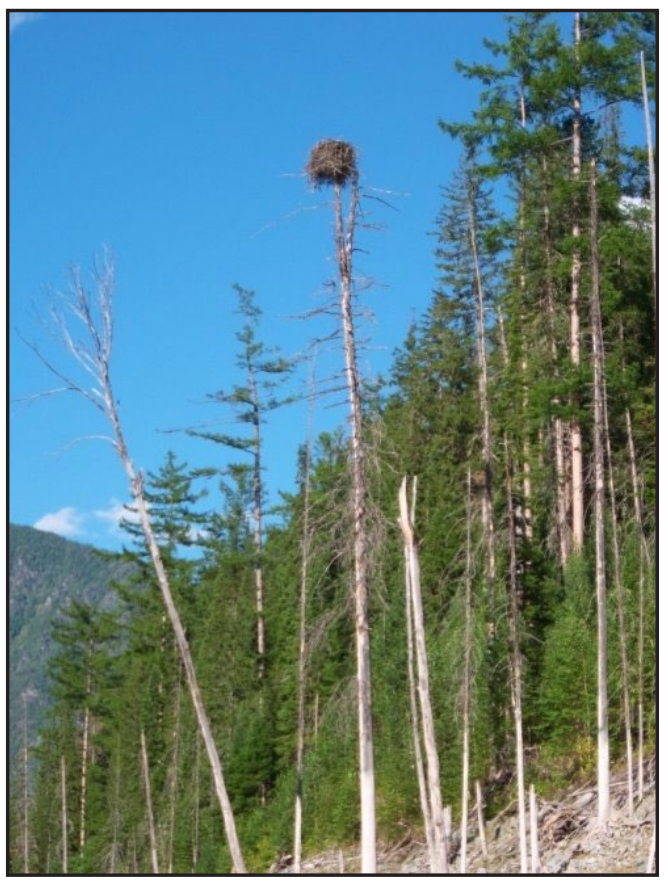

Типичное гнездо скопы из саянской популяции. Фото М. Аубинина.

Typical nest of the Osprey from the Sayan population. Photo by M. Dubinin.

sea level altitude (fig. 1-2). This nest was built on horizontal beam of metallic pillar of high-voltage powerline near Abaza Akdovurak highway (fig. 2). At the moment of the discovery the female was in the nest (possibly warming the young nestlings), the male was sitting nearby. Taking into account the narrow width and shallow depth of Bolshoy On river in this place, one can assume that the feeding place for the pair is the Marankul lake situated $4.5 \mathrm{~km}$ away from the discovered nest.

During the period from 2000 to 2011 Ospreys were absent on the discovered area, and this pair definitely appeared after 2011.

Thus in June, 2016 we discovered in Western Sayan the second Osprey nest situated in altitude range more than $1000 \mathrm{~m}$ above sea level, and the first situated on metallic pillar of high-voltage powerline.

Рис. 1. Распространение скопы (Pandion haliaetus) в Западном Саяне: 1 - гнездовые участки, выявленные

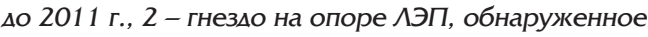
в 2016 r.

Fig. 1. Distribution of the Osprey (Pandion haliaetus) in Western Sayan: 1 - breeding territories discovered before 2011, 2 - nest on the power pole, discovered in 2016. 
Рис. 2. Гнездо скопы на опоре АЭП в Запацном Саяне. 22.06.2016. Фото И. Карякина и М. Проммера.

Fig. 2. Nest of the Osprey on the electric pole in Western Sayan. 22/06/2016.

Photos by I. Karyakin and M. Prommer. единственная точка гнездования, выбиваюшаяся из этого высотного диапазона, была выявлена на оз. Бедуйское в верховьях р. Белуй. ЗАесь скопы устроили гнез$\Delta о$ на усыхаюшем дереве, произрастаюшем на высоте 1440 м нах уровнем моря.

В ходе маршрута влоль р. Бол. Он 22 июня 2016 г. было обнаружено жилое гнездо скопы, располагавшееся в высотном диапазоне 1321 м нал уровнем моря (рис. 1-2). Это гнезАо птицы устроили нетрадиционно - на горизонтаяьной перекладине метамиической опоры

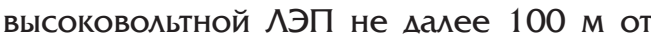
автотрассы Абаза - Акдовурак (рис. 2). В момент обнаружения гнезда самка нахоАилась в гнездовой постройке (вероятно, обогревала мелких птенцов), самец находился рялом на присаче. Учитывая небольшую ширину и глубину реки Бол. Он в Аанном месте, можно предполагать, что кормовым водоёмом пары является оз. Маранкуль, расположенное в 4,5 км от выявленного гнезда, на котором, кстати, одиноч- ная скопа наблюдаиась несколькими годами ранее.

Следует отметить, что в период с 2000 по 2011 гг. на выявленном участке скопы отсутствоваяи, и эта пара появияась на гнездовании определённо после 2011 г.

Гнездование скоп на опорах АЭП является распространенным явлением в США и странах зарубежной Европы (Cramp, Simmons, 1980; Hemke, 1983; Ruhle, 1985; Palmer, 1988; Poole, 1989; Meyburg et al., 1995; Henny, Kaiser, 1996; Ewins, 1996; 1997; Mebs, Schmidt, 2014), однако в России такие случаи единичны и известны лишь в бассейне Волги (Бакка и мр., 2008; Аинкевич, 2011; Карякин, 2016), а в Саянах до последнего времени вовсе не регистрировались.

Таким образом, в июне 2016 г. нами было выявлено в Запанном Саяне второе гнездо скопы, располагавшееся в высотном диапазоне более 1000 м нам уровнем моря, и первое, устроенное на метамической опоре АЭП.

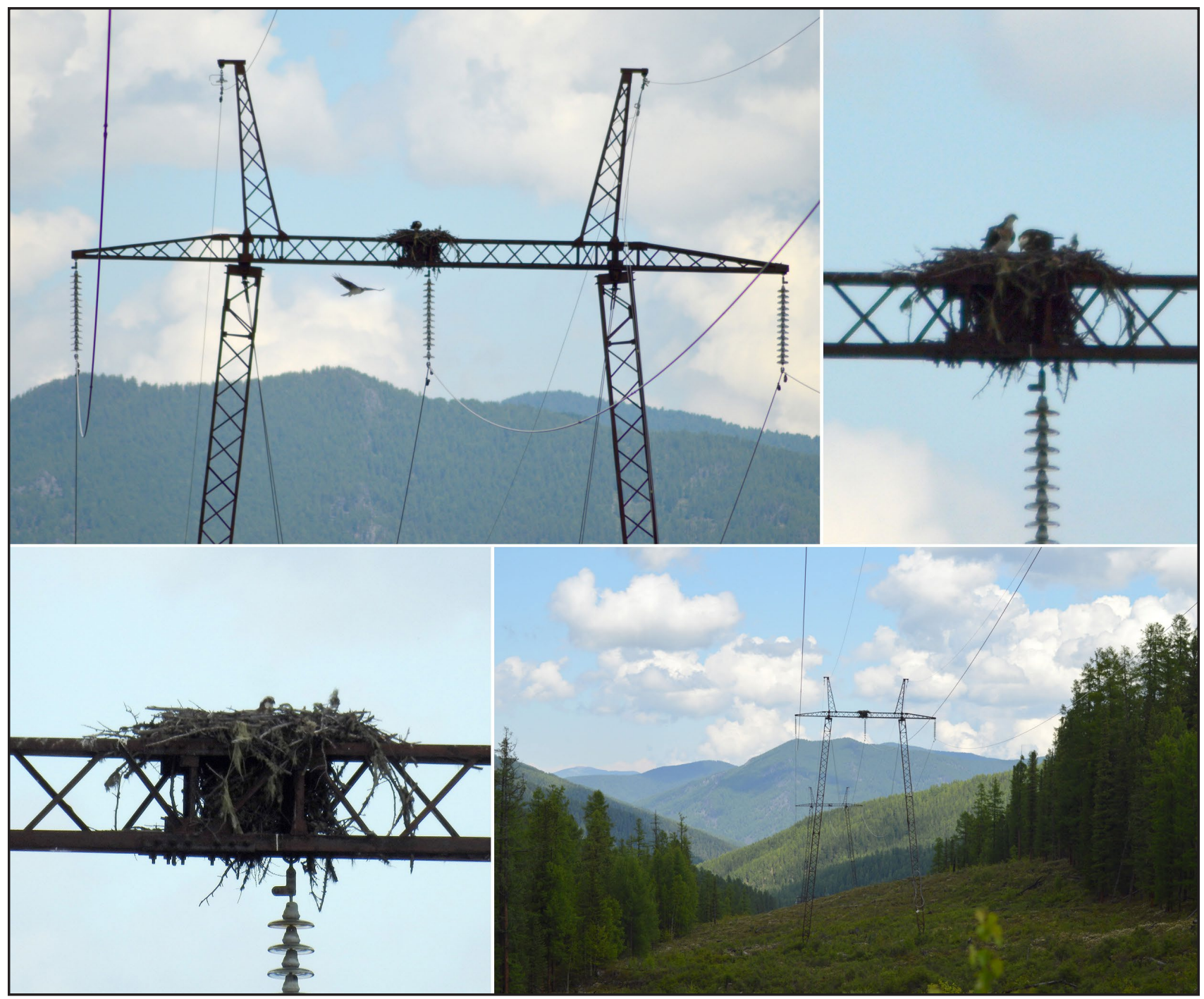




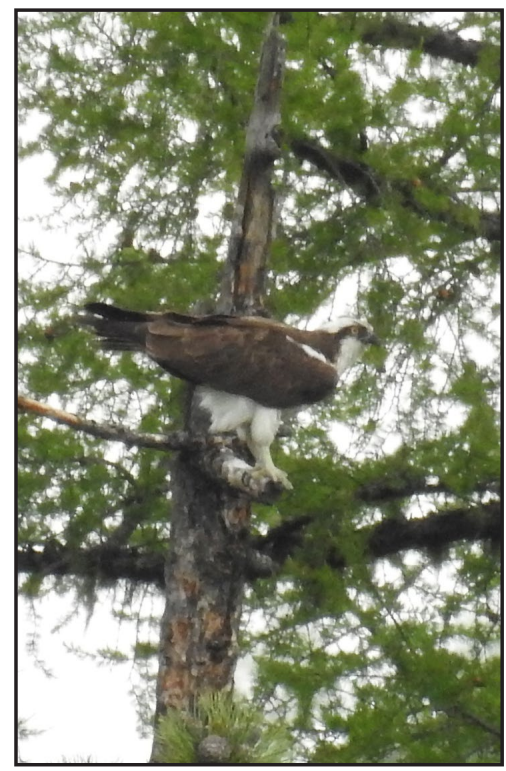

\section{Митература}

Бакка С.В., Карякин И.В., Москаиик А.Н. Первый случай гнез-

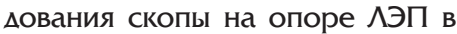
Поволжье, Россия. - Пернатые хишники и их охрана. 2008. № 11. C. 76. [Bakka S.V., Karyakin I.V., Moskalik L.N. The First Record of the Osprey Breeding on the Electric Pole in Povolzhye, Russia. - Raptors Conservation. 2008. 11: 76]. URL: http://rrrcn. ru/ru/archives/25034 Аата обрашения: 10.03.2017.

Вамюх В.Н. Территориальное размешение и состояние численности скопы на реках Саян и Присаянья. - Территориальное размешение и экология птиц юга Средней Сибири. Красноярск, 1991. С. 72-81. [Valyukh

Самец скопы на присаце. Фото М. Проммера.

Make of the Osprey on perch. Photo by M. Prommer.
Озеро Ойское в Запацном Саяне, гле скопа найдена на гнездовании П.П. Сушкиным (1914) в начале $X X$ стометия, но в настояшее время не гнездится. Фото И. Карякина.

Oysskoye Lake in the Western Sayan - here the breeding osprey was observed by Sushkin (1914) in the early twentieth century, but now ospreys on this territory do not breeding. Photo by I. Karyakin. haliaetus (Linnaeus, 1758). - Red Data Book of the Republic of Khakassia. In 2 vol. The Rare and Endangered Species of Animals / Eds. A.P. Savchenko, A.A. Baranov, S.M. Chuprov, Yu.N. Litvinov, Yu.N. Baranchikov, G.A. Sokolov. Second edition. Krasnoyarsk-Abakan, 2014: 1-354. (in Russian)]. URL: http://oopt.aari.ru/ ref/1153 Аата обрашения: 10.03.2017.

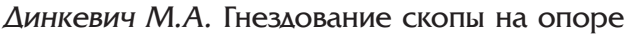
АЭП в дельте Волги, Астраханская область, Россия. - Пернатые хишники и их охрана. 2011 . № 22. C. 198-200. [Dinkevich M.A. Nesting of the Osprey on the Electric Pole in the Volga Delta, Astrakhan District, Russia. - Raptors Conservation 2011. 22: 198-200]. URL: http://rrrcn.ru/ru/ archives/12800 Аата обрашения: 10.03.2017.

Карякин И.В. Орлы России и Казахстана: места обитания и зоны электросетевой опасности. Новосибирск: Сибэкоцентр, 2016. 36 с. [Karyakin I.V. Eagles of Russia and Kazakhstan: ranges and electric-grid danger zones. Novosibirsk: Sibecocentr, 2016: 1-36]. URL: http:// rrrcn.ru/ru/archives/26593 Аата обрашения: 10.03.2017.

Ковырцев И. Скопы в заповеднике стало больше. - Государственный природный биоссерный заповедник "Саяно-Шушенский". 2012. [Kovyrtsev I. In the State Nature Reserve has increased the number of Ospreys. - State Nature Biosphere Reserve "Sayano-Shushenskiy". 2012. (in Russian)]. URL: http://sayanzapoved.ru/index.php/novosti/115-skopy-v-zapovednikestalo-bolshe.html Аата обрашения: 10.03.2017.

Кохановский Н.А. К экологии хишных птиц южной части Средней Сибири. - Территориальное размешение и экология птиц юга Средней Сибири. Красноярск, 1991. С. 81-88. [Коhanovskiy N.A. To the ecology of birds of prey in the southern part of Central Siberia. - Territorial location and ecology of birds in the south of Central Siberia. Krasnoyarsk, 1991: 81-88. (in Russian)].

Кустов Ю.И. Численность и территориальное распределение хищных птиц в Минусинской котловине. - Фауна и экология позвоночных животных. М.: изА-во Московского гос. [Gavrilov I.K., Baranov A.A. Osprey Pandion

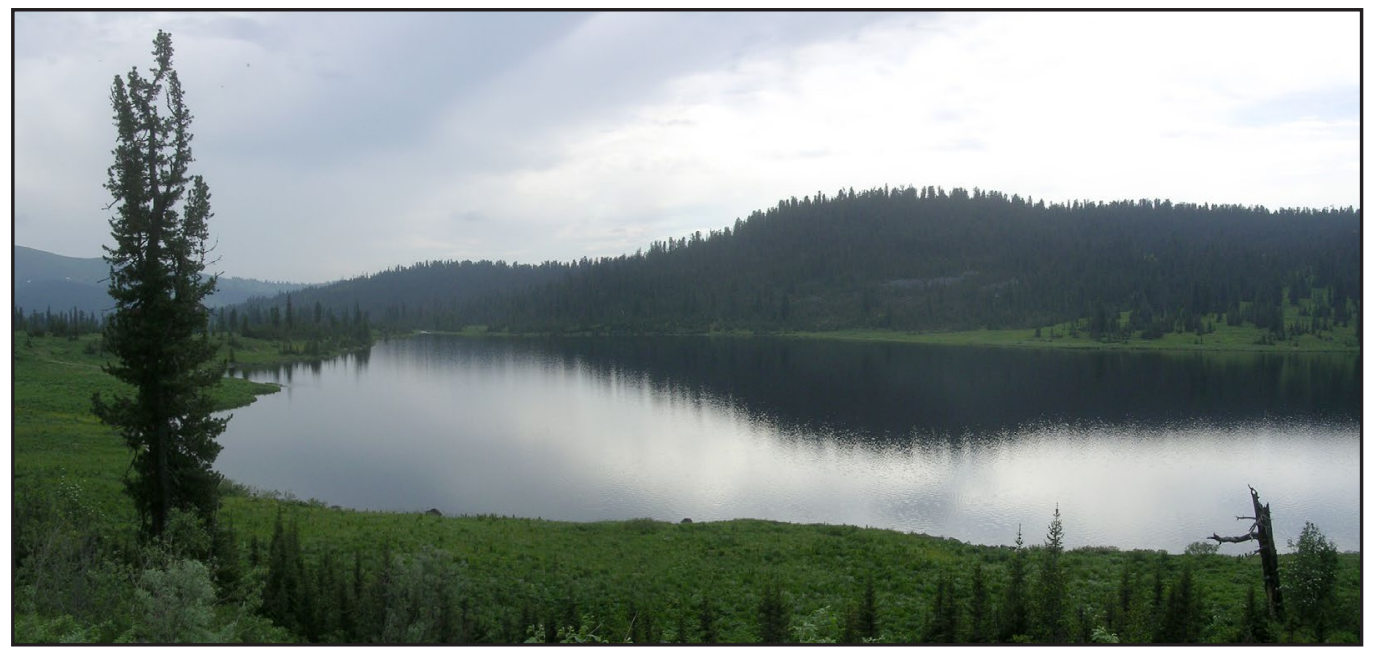


пед. ин-та им. В.И. Аенина, 1978. С. 91-97. [Kustov Yu.I. Population numbers and territorial distribution of birds of prey in the Minusinsk depression. - Fauna and ecology of vertebrates. Moscow, 1978: 91-97. (in Russian)].

Кустов Ю.И. Хишные птицы Минусинской котловины. - Миграции и экология птиц СреАней Сибири. Новосибирск, 1982. С. 49-59. [Kustov Yu.I. Birds of prey of the Minusinsk depression. - Migration and ecology of birds in Central Siberia. Novosibirsk, 1982: 49-59. (in Russian)].

Савченко А.П., Баранов А.А., Гавримов И.К., Стахеев В.А., Мейдус А.В. Скопа Pandion haliaetus (Linnaeus, 1758). - Красная книга Красноярского края: В 2 т. Т. 1. Редкие и нахоАяшиеся под угрозой исчезновения виды животных / Под ред. А.П. Савченко, А.А. Баранов, В.А. Зацеленов, Ю.Н. Аитвинов, О.В. Тарасова, М.П. Тиунов. 3-е изА. Красноярск, 2011. 205 с. [Savchenko A.P., Baranov A.A., Gavrilov I.K. Staheev V.A., Meydus A.V. Osprey Pandion haliaetus (Linnaeus, 1758). - Red Book of the Krasnoyarsk Kray. The Rare and Endangered Species of Animals / Eds. A.P. Savchenko, A.A. Baranov, V.A. Zadelenov, Yu. N. Litvinov, O.V. Tarasova, M.P. Tiunov. 3 edition. Krasnoyarsk, 2011: 1-205. (in Russian)]. URL: http://oopt.aari.ru/ ref/128 Аата обрашения: 10.03.2017.

Стахеев В.А. Скопа в Алтайском и Саяно-Шушенском заповедниках. - Охрана хишных птиц. M., 1983. C. 159-161. [Staheev V.A. Osprey in the Altaiskiy and Sayano-Shushenskiy State Nature Reserves. - Conservation of birds of prey. Moscow, 1983: 159-161. (in Russian)].

Стахеев В.А. О гнездовании скопы при формировании Саянского водохранияища. - Изучение птиц СССР, их охрана и рационаиьное использование. А., 1988. С. 257-258. [Staheev $V . A$. On the nesting of the Osprey during the formation of the Sayan reservoir. - Researching birds of the USSR, their conservation and rational use. Leningrad, 1988: 257-258. (in Russian)].

Стахеев В.А. Опыт соормирования устойчивой гнездящейся группировки скопы (Pandion haliaetus L.) для восстановления численности и гнездовых ареалов редких видов птиц в Запацном Саяне и смежных районах Минусинской и Тувинской котловин. - Отчет по НИР. Шушенское: Саяно-Шушенский заповедник, 2003. 34 c. [Staheev V.A. The experience of creating a sustainable breeding group of the Osprey (Pandion haliaetus L.) for the restoration of populations and breeding ranges of rare bird species in the Western Sayan and adjacent areas of the Minusinsk and Tuva depressions. - Report on research. Shushenskoe: Sayano-Shushenskiy State Nature Biosphere Reserve, 2003: 1-34. (in Russian)].

Стахеев В.А., Ирисова Н.А., Полушкин А.M. Хишные птицы и совы заповедников Аитая и Саян. - Хишные птицы и совы в заповедниках РСФСР. М., 1985. С. 30-45. [Staheev V.A., Irisova N.L., Polushkin D.M. Birds of prey and owls of the State Nature Reserves in the Altai and Sayan.
- Birds of prey and owls in the State Nature Reserves of the RSFSR. Moscow, 1985: 30-45. (in Russian)].

Сушкин П.П. Птицы Минусинского края, Запацного Саяна и Урянхайской земли. М., 1914. 551 c. [Sushkin P.P. Birds of the Minusinsk Kray, Western Sayan and Uryanhaiskaya Land. Moscow, 1914: 1-551. (in Russian)].

Тугаринов А.Я., Бутурлин С.А. Материамы по птицам Енисейской губернии. - Записки Красноярского подотлела Вост.-Сиб. отА-ния ИРГО по фриз. географии. Красноярск. 1911. T. 1. Вып. 2-4. С. 1-440. [Tugarinov A.Ya., Buturlin S.A. Materials on the birds of the Yenisei province. - Notes of the Krasnoyarsk sub-department of the East-Siberian branch of the Imperial Russian Geographical Society on Physical Geography. Krasnoyarsk. 1911. 1 (2-4): 1-440.].

Cramp S., Simmons K.E.L. Osprey. - The birds of the Western Palearctic. Vol. 2: hawks to bustards. Oxford, UK: Oxford Univ. Press, 1980: 265-277.

Ewins P.J. The use of artificial nest sites by an increasing population of Osprey in the Canadian Great Lakes basin. - Raptors in Human Landscapes / Eds. D.M. Bird, D.E. Varland and J.J. Negro. London: Academic Press, 1996: 109-123.

Ewins P.J. Osprey (Pandion haliaetus) populations in forested areas of North America: changes, their causes and management recommendations. - J. Raptor Res. 1997. 31: 138-150.

Hemke E. Von Nisten des Fischadlers, Pandion haliaetus, in der Deutschen Democratischen Republik (DDR). - Lounais-Hämeen Luonto. 1983. 69: 32-35.

Henny C.J., Kaiser J.L. Osprey population increase along the Willamette River, Oregon, and the role of utility structures, 1976-1993. - Raptors in Human Landscapes / Eds. D.M. Bird, D.E. Varland and J.J. Negro. London: Academic Press, 1996: 97-108.

Mebs T., Schmidt D. Die Greifvögel Europas, Nordafrikas und Vorderasiens: Biologie, Kennzeichen, Bestände. Kosmos Verlag, Stuttgart, 2014: 1-496.

Meyburg B.-U., Manowsky O., Meyburg C. Breeding success of tree- and pylon-nesting Ospreys Pandion haliaetus in Germany. - Vogelwelt, 1995. 116: 219-224. (in German with English summary). URL: http://www.raptor-research.de/pdfs/a_rp500p/a_rp511.pdf Date accessed: 10/03/2017.

Palmer R.S. Handbook of North American birds, Vol. 4: diurnal raptors. Pt. 1. New Haven, CT: Yale Univ. Press., 1988: 1-448.

Poole A. Regulation of Osprey (Pandion haliaetus) populations: the role of nest site availability. - Raptors in the modern world / Eds. B.-U. Meyburg and R.D. Chancellor. Berlin: WWGBP, 1989: 227-234.

Ruhle D. Zum Vorkommen des Fischadlers (Pandion haliaetus (L.) im Bezirk Cottbus. - Natur Landsch. Bez. Cottbus. 1985. 7: 64-72. 